\title{
PENDAMPINGAN PASAR MODAL PADA SISWA SMKN 2 KEDIRI
}

\author{
Novie Astuti Setianingsih ${ }^{1}$, Atik Tri Andari², Wiwiek Kusumaningasmoro ${ }^{3}$, \\ Eti Putranti ${ }^{4}$, Elmi Rakhma Aalin ${ }^{5}$ \\ 1), 2), 3), 4), 5) Politeknik Negeri Kediri PSDKU \\ ${ }^{1}$ Email: viecoll77@gmail.com \\ 2Email: triatik1213@gmail.com \\ ${ }^{3}$ Email: wiwikasmoro@gmail.com \\ ${ }^{4}$ Email: etiputranti@gmail.com \\ ${ }^{5}$ Email: elmirakhma@gmail.com
}

\begin{abstract}
The purpose of the implementation of community service activities is to prepare SMKN 2 Kediri students and millennials to better understand and master the Capital Market. The method of implementation uses the experiential learning method, which is a learning method from experience. The method used is the lecture method, the question and answer method and the simulation method. For simulation method by doing multiple choice questions, crossword simulation (TTS), kotak katik simulation, case debate simulation and stock treading simulation in Indonesia stock exchange using Reliance Securities and MNC Securities. The implementation of Community Service was held on October 1, 2019 until October 14, 2019 for a period of 10 days attended by 22 participants and carried out at the Indonesia Stock Exchange Politeknik Negeri Malang PSDKU Kediri.
\end{abstract}

Keywords: workshop, capital markets, students

\section{ANALISIS SITUASI}

Perekonomian Indonesia semakin membaik sehingga mempengaruhi hargaharga saham di pasar modal. Semakin membaiknya perkembangan di pasar modal menjadikan tantangan bagi pendidik untuk mempersiapkan para siswa, mahasiswa dan generasi milenial untuk lebih memahami dan menguasai tentang Pasar Modal.

Pasar sebagai instrumen keuangan yang diperjualbelikan dalam jangka panjang bisa berupa modal ataupun hutang yang diterbitkan public authoroties, pemerintah dan swasta merupakan definisi dari Pasar Modal.(Husnan; 2009). Pasar Modal merupakan penawaran umum dan perdagangan efek perusahaan publik yang diterbitkan lembaga dan profesi yang berkaitandenan efek (Tandelilin; 2010). Dari pendapat para ahli tersebut dapat disimpulkan bahwa pasar modal dibentuk untuk menghubungkan investor (pemodal) dengan perusahaan atau institusi pemerintah yang memerlukan modal.

Untuk memperdalam dan menganalisa investasi dalam bentuk saham dapat dianalisis dengan 2 cara yaitu: analisis fundamental dan analisis teknikal.

\section{Analisis Fundamental}

Banyak faktor yang mempengaruhi penjualan dan biaya-biaya, faktor yang tidak bisa dikendalikan oleh perusahaan Misalnya. Suku Bunga, Pertumbuhan Ekonomi, Harga Minyak, dan sebagainya. Banyak faktor yang mempengaruhi harga saham, maka akan melakukan analisis fundamental diperlukan beberapa tahun analisis. Tahapanya yaitu:

a) Kondisi mikro ekonomi atau kondisi pasar Kondisi ekonomi dan keadaan berbagai variabel utama seperti laba yang diperoleh oleh perusahaan-perusahaan dan tingkat bunga. Variabel-variabel tersebut sangat mempengaruhi keputusan-keputusan investasi yang akan diambil oleh para 
pemodal. Apabila kondisi perekonomian mepengaruhi kondisi pasar, maka pada gilirannya kondisi pasar akan mempengaruhi para pemodal. Sulit bagi pemodal untuk memperoleh hasil investasi yang berkebalikan dengan kecenderungan pasar.

b) Memperkirakan Perubahan didalam perekonomian/Pasar

Pemodal ingin memperkirakan gejalagejala perekonomian dimasa yang akan datang untuk memperkirakan arah gerakan pasar, dan berapa lama perubahan tersebut mungkit terjadi.Arah gerakan kondisi perekonomian dan pasar tersebut berguna bagi pemodal untuk mengambil sebuah keputusan.

c) Penggunaan indikator moneter untuk memprakirakan kondisi pasar.

Prakiraan perubahan jumlah uang yang beredar juga diharapkan akan mempengaruhi kegiatan ekonomi. Untuk kegiatan ekonomi dimasa yang bakan datang, tergantung pada perubahan uang yang beredar.

d) Kondisi ekonomi dan kondisi pasar Kondisi pasar saat ini mencerminkan harapan para pemodal terhadap kondisi ekonomi dimasa yang akan datang. Bahwa pasar mungkin mengantisipasi perkembangan tingkat bunga, sehingga analisis seri data menunjukan hasil yang tidak sesuai harapan. Sehingga analisis seri data secara synchronous menunjukan hasil yang tidak sesuai dengan harapan.

e) Diikuti dengan analisis industri.

f) Akhirnya analisis kondisi spesifik perusahaan

\section{Analisis Teknikal}

Analisis Teknikal memiliki banyak tools yang bisa digunakan untuk membantu trader dalam menganalisis. Contohnya Trend Line, Rectangle, Fibonacci Retracement, dan lain sebagainya. Yang paling banyak dipakai misalnya adalah Trend Line. Trend line adalah garis imajinatif yang dibuat untuk menunjukkan kecenderungan (trend) pergerakan harga saham. Misalnya kita bisa tahu harga sedang uptrend (cenderung naik), downtrend (cenderung turun) atau sideways (datar). Dengan mengetahui berbagai pola ini Anda akan dapat mengantisipasi kemungkinan terjadinya perubahan harga.

\section{METODE PELAKSANAAN}

Kegiatan Pengabdian Kepada Masyarakat ini sasarannya adalah siswa siswi SKMN 2 Kediri. Meode pelaksanaannya dengan mengguakan metode experiental learning yaitu metode pembelajaran dari pengalaman. Metode yang digunakan adalah:

1. Metode ceramah

Metode ceramah ini adalah memberikan informasi atau materi secara lisan baik formal maupun informal kepada siswa.

2. Metode tanya jawab

Metode pembelajaran dalam bentuk pertanyaan yang harus dijawab, terutama dari tutor kepada para peserta atau bisa jadi sebaliknya dari para peserta kepada tutor.

3. Metode simulasi

Metode simulasi adalah metode pembelajaran dengan pelatihan yang memperagakan sesuatu yang mirip dengan keadaan sesungguhnya dengan melalui simulasi mengerjakan soal multiple choice, simulasi teka teki silang (TTS), simulasi kotak katik dan simulasi debat kasus dan simulasi treding saham di bursa efek indonesia memakai reliance sekuritas.

\section{HASIL DAN PEMBAHASAN}

Pelaksanaan Pengabdian Kepada Masyarakat ini berlangsung pada tanggal 1 Oktober 2019 sampai dengan tanggal 14 Oktober 2019 selama kurun waktu 10 hari dengan dihadiri 22 peserta dan dilaksanakan di Laboratorium Galeri Investasi Bursa Efek Indonesia Politeknik Negeri Malang PSDKU Kediri. 


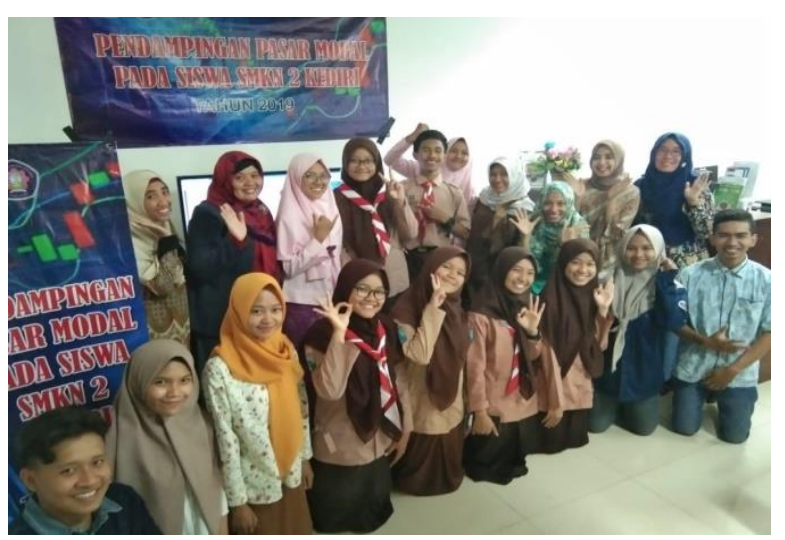

Gambar 1. Peserta pelatihan

Pelaksanaan kegiatan meliputi:

1. Metode ceramah

Metode ini diisi dengan memberikan materi tentang pasar modal. Materi yang dibahas adalah:

- Analisis Teknikal

Analisis Teknikal memiliki banyak tools yang bisa digunakan untuk membantu trader dalam menganalisis. Contohnya Trend Line, Rectangle, Fibonacci Retracement, dan lain sebagainya. Yang paling banyak dipakai misalnya adalah Trend Line. Trend line adalah garis imajinatif yang dibuat untuk menunjukkan kecenderungan (trend) pergerakan harga saham. Misalnya kita bisa tahu harga sedang uptrend (cenderung naik), downtrend (cenderung turun) atau sideways (datar). Dengan mengetahui berbagai pola ini Anda akan dapat mengantisipasi kemungkinan terjadinya perubahan harga.

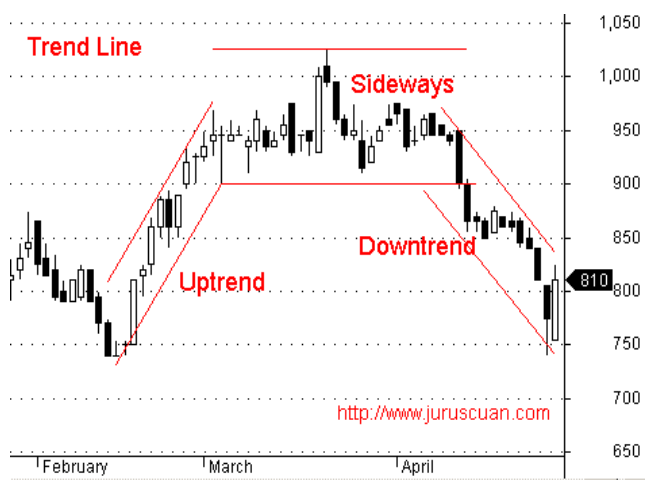

Gambar 2. Trend Line

- Analisis fundamental

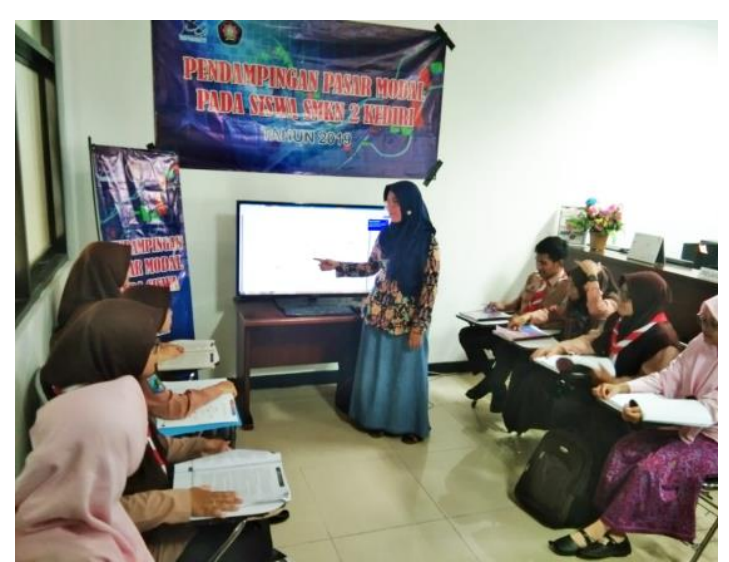

Gambar 3. Metode ceramah

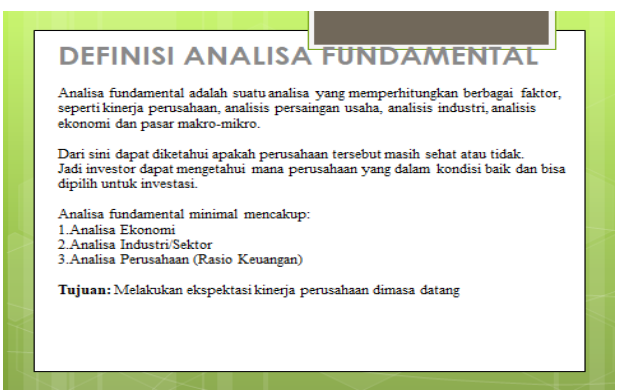

Gambar 4. Slide materi 1

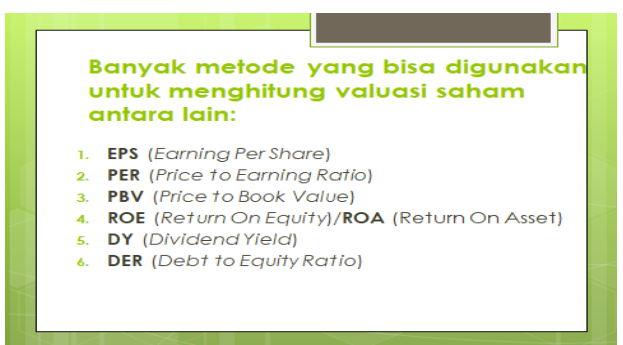

Gambar 5. Slide materi 2

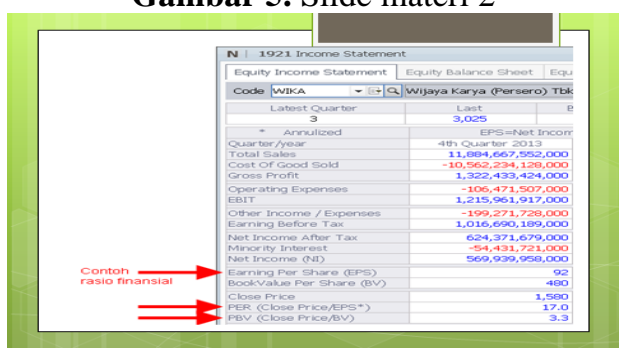

Gambar 6. Slide materi 3

2. Metode tanya jawab

Metode ini diisi dengan memberian pertanyaan kepada para peserta dan para

Novie Astuti Setianingsih - Pendampingan Pasar Modal Pada Siswa SMKN 2 Kediri 
peserta dipersilahkan juga untuk menanyakan materi yang kurang paham. Metode tanya jawab ini dilaksanakan berdasarkan materi pasar modal.

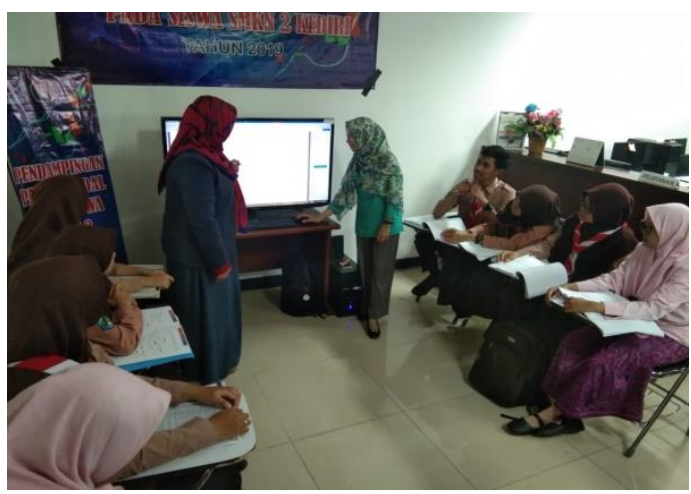

Gambar 7. Metode tanya jawab

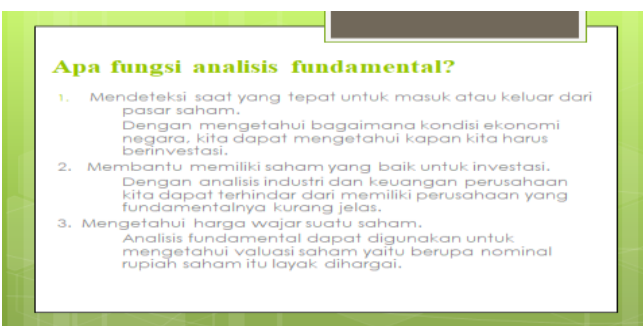

Gambar 8. Slide tanya jawab

3. Metode simulasi

Metode simulasi ini diisi dengan memberikan simulasi mengerjakan soal multiple choice, simulasi teka teki silang (TTS), simulasi kotak katik, simulasi debat kasus dan simulasi treding saham.

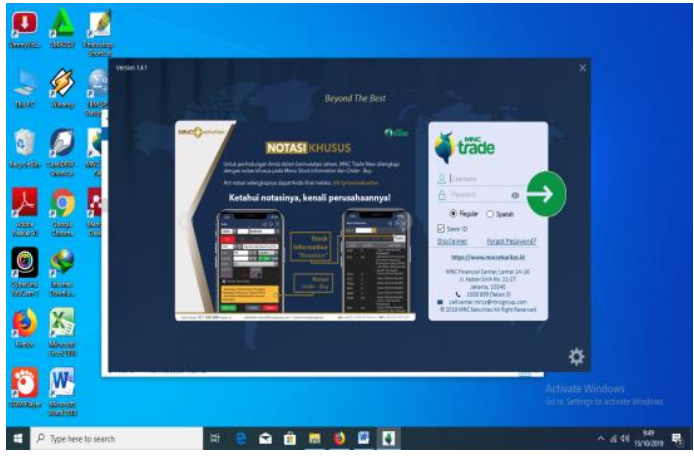

Gambar 9. Login MNC Sekuritas

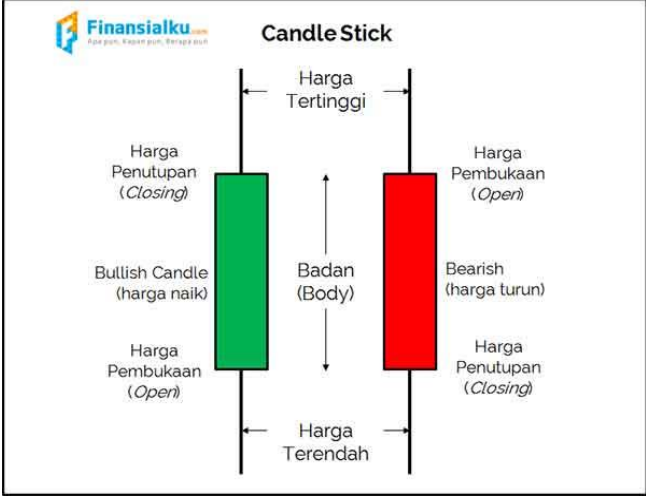

Gambar 10. Candle stick

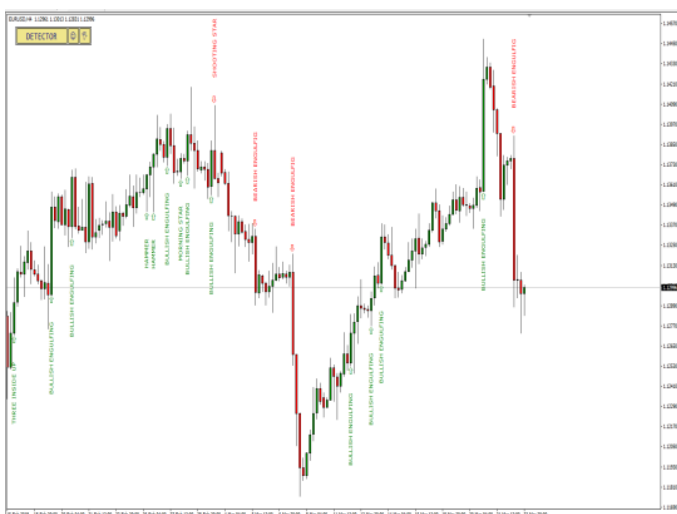

Gambar 11. Grafik candle stick

Setelah pelatihan diselenggarakan, peserta lebih memahami konsep materi pasar modal, sehingga termotivasi untuk belajar lebih dalam mengenai pasar modal untuk mempersiapkan olimpiade. Hal terakhir yang dilakukan dalam rangkaian kegiatan ini adalah memberikan angket kepuasan sekaligus keberhasilan dari pelaksanaan kegiatan ini. Berdasarkan hasil angket tersebut, disimpulkan bahwa secara umum para peserta merasa puas dengan pelatihan ini, mereka terinspirasi sekaligus termotivasi untuk mengikuti olimpiade pasar modal serta lebih meningkatkan keinginan siswa SMKN 2 Kediri untuk berinvestasi di pasar modal. Jadi bisa meningkatkan jumlah investor-investor muda di kalangan anak muda sekarang ini.

\section{KESIMPULAN}

Berdasarkan hasil pelaksanaan kegiatan pengabdian masyarakat yang telah dilakukan, maka dapat ditarik kesimpulan bahwa kegiatan ini dapat 
memberikan pengetahuan lebih dalam tentang pasar modal, membangkitkan minat para peserta untuk mengikuti olimpiade pasar modal, dan memperkenalkan Galeri Investasi Politeknik Negeri Malang PSDKU Kediri kepada masyarakat. Kegiatan pengabdian ini memberikan manfaat yang besar, yaitu meningkatkan pengetahuan siswa-siswi SMKN 2 Kediri di pasar modal serta menarik minat para pemuda untuk berinvestasi di pasar modal dan mampu mengaplikasikan pengetahuannya di lantai Bursa Efek Indonesia. Pelaksanaan kegiatan pelatihan pasar modal bagi siswa-siswi SMKN 2 Kediri bertempat di Laboratorium Galeri Investasi Bursa Efek Indonesia (GI-BEI) Politeknik Negeri Malang PSDKU Kediri pada tanggal 1 Oktober 2019 sampai 14 Oktober 2019 Pelatihan berjalan dengan lancar sesuai dengan apa yang direncanakan. Peserta pelatihan ada 22 orang dan semua peserta hadir dalam pelatihan. Hal tersebut menunjukkan minat yang tinggi dari para peserta untuk mengikuti pelatihan guna memperdalam pemahaman mengenai pasar modal.

\section{DAFTAR PUSTAKA}

Anoraga, Pandji dan Piji Pakarti. 2001. Pengantar Pasar Modal. Jakarta : PT. Rineka Cipta.

Ang, Robert. 1997. Buku Pintar Pasar Modal Indonesia (The Intelligent Guide to. Indonesian Capital Market). Jakarta: Mediasoft Indonesia.

Bambang Riyanto, 2005, Dasar-dasar Pembelanjaan Perusahaan. Edisi keempat. Yogyakarta; BPFE

Darmadji Tjipto dan Hendry M Fakhruddin, 2001. Pasar Modal di Indonesia, Jakarta: Salemba Emapat

Fernandez, Rodriguez, F. Gonzales Marcel, C. Sosvilla Rivero S. 2000. On The Profitability of Technical Trading Rules Based on Artificial Neural Network : Evidence from the Madrid
Stock Market, Economic Letters, Elsevier Vol. 69(1), 89-94

Henry Simamora. 2000. Basis Pengambilan Keputusan Bisnis. Jakarta: Salemba Empat

James C, Van Horne dan John M. Wachowicz. 2005. Manajemen Keuangan. Bandung : Pustaka

Jogiyanto, 2000.Teori Portofolio dan Analisis Investasi, Edisi Kedua . Yogyakarta:BPFE

Sunariyah. 2004. Pengantar Pengetahuan Pasar Modal. Edisi Kelima. Bandung: CV. Alfabeta

Suad Husnan dan Enny Pudjiastuti. 2004. Dasar-dasar Manajemen Keuangan. Yogyakarta:UPP. AMP YKPN.

Tandelilin. 2010. Fortofolio dan Investasi. Yogyakarta: Konisius

Valle DJ. 1998. Peptic Ulcer Disease and Related Disorders, Harrison's Principle. Internal Medicine. 